\title{
Outward foreign direct investment and employment in Japan's manufacturing industry
}

\author{
Gu Huijie* (1)
}

\author{
*Correspondence: \\ Angela_g3593@yahoo.co.jp \\ Graduate School \\ of International \\ Development, Nagoya \\ University, Nagoya, Japan
}

\begin{abstract}
This paper uses the input-output analysis to investigate the impact of Japan's outward foreign direct investment (FDI) on domestic production and employment in the manufacturing industry. With the expansion of Japan's overseas business, there is a fear that the production of overseas affiliates will replace parent country's export and output. As a consequence, it will cause job losses in the home country, especially in laborintensive manufacturing industry. On the other hand, outward FDI also has export promotion effect on domestic economy of the home country. Parent enterprises need to export capital and intermediate goods for the construction and production of affiliates abroad in the early stage of outward FDI. This effect will enhance the export and employment of the home country. The results of this paper suggest that the negative impact of export substitution effect and inverse import effect is greater than the positive impact of export promotion effect from 2000 to 2014, which means that the total effect of Japan's outward FDI is negative and it causes the decrease in domestic production in Japan's manufacturing industry. As a result, it leads to the unemployment in Japan, which is called the "Hollowing-Out" effect. Also, this paper compares the calculation result of the period 2000-2014 with the period of 1990-1999 and finds that the "Hollowing-Out" of Japan has become more serious in recent years with the increase in Japan's outward FDI. It is necessary to change the structure of economy in Japan to alleviate the unemployment problem caused by outward FDI.
\end{abstract}

Keywords: Outward FDI, Domestic output, Employment, Input-output analysis

\section{Background}

According to Japan External Trade Organization (JETRO), Japan has increased its outward FDI a lot from 1996 to 2016 with the rapid expansion of overseas affiliates. The flow of Japan's outward FDI has ranked second in the world for many years until 2015. Figure 1 shows the flow of Japan's outward FDI from 1996 to 2016. We can observe that there is a peak in 2008 which is the year of global financial crisis. Japan Bank for International Corporation did financing to support Japanese overseas firms especially in North America in this year. Then, Japan's outward FDI slumped because of the global depression and recovered rapidly from 2011. In the Basic Survey on Overseas Business Activity (BSOBA) conducted by Japan Ministry of Economy, Trade and Industry (METI), the ratio of overseas production for Japanese manufacturing industries has marked a record

(c) The Author(s) 2018. This article is distributed under the terms of the Creative Commons Attribution 4.0 International License (http://creativecommons.org/licenses/by/4.0/), which permits unrestricted use, distribution, and reproduction in any medium, provided you give appropriate credit to the original author(s) and the source, provide a link to the Creative Commons license, and indicate if changes were made. 

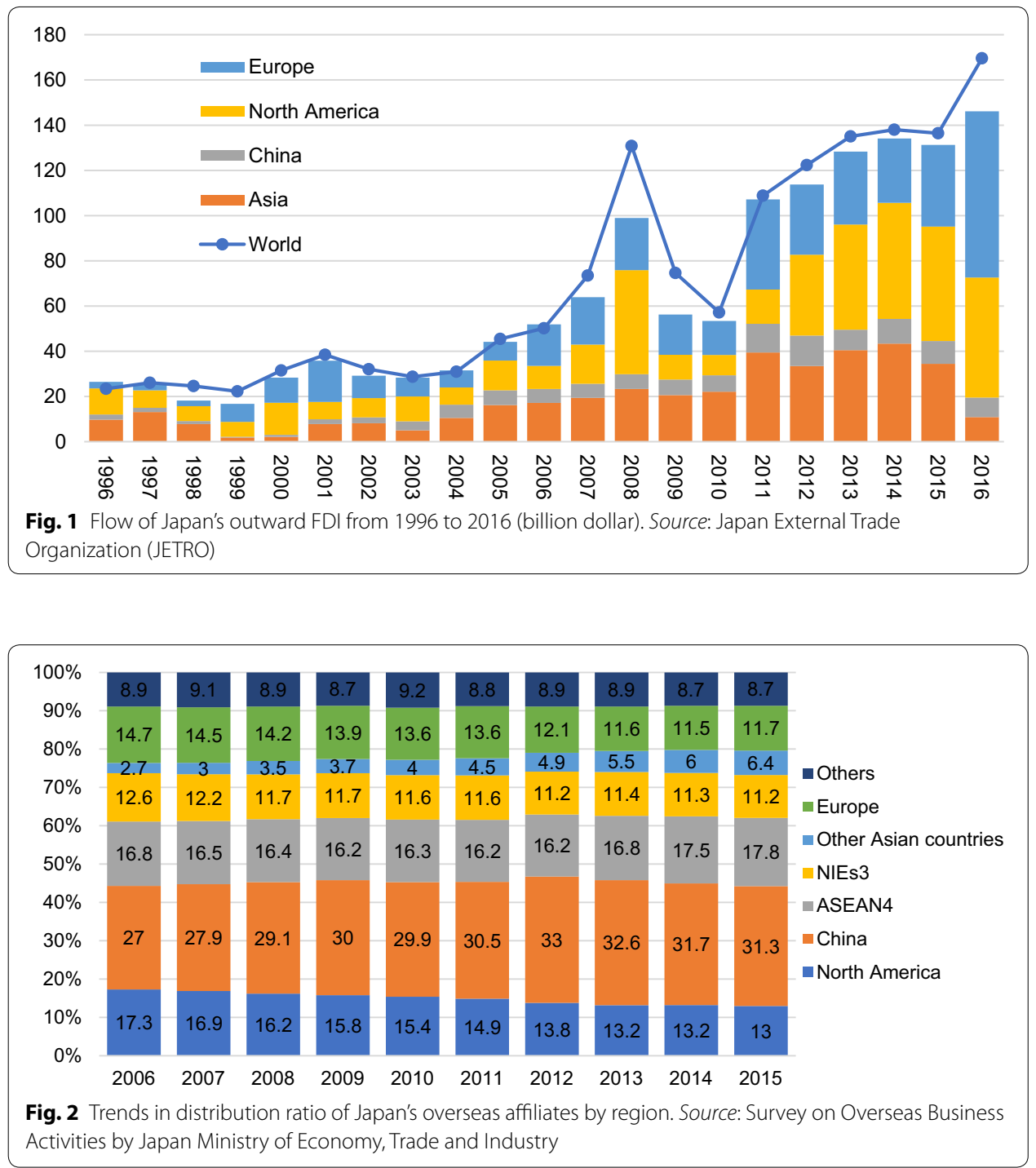

high $-25.3 \%$ in 2015. From the trend of Fig. 1, it is obvious that Japan has improved its overseas expansion ceaselessly through outward FDI.

Figure 2 shows the trends in distribution ratio of Japan's overseas affiliates by region. It can be observed from Fig. 2 that almost 30\% of Japanese overseas affiliates are located in China, and other Asian countries also account for about 35\%. Japanese multinational corporations (MNCs) established many affiliates in China and other Asian countries in recent decades. An important reason of this phenomenon is that Japanese MNCs relocated their production facilities to these neighboring developing countries through outward FDI to exploit low-cost factors of production. Theoretically, this kind of FDI is called vertical FDI which is a strategy for MNCs to utilize the comparative advantage of the host country. At the same time, China and these Asian countries are also huge sales markets which have great potential. $69.4 \%$ of Japanese enterprises consider the most important deciding factor for overseas investments is that market demand is strong or prospective in the future in host countries. Other major factors include 
that other Japanese MNCs have successful experience, including delivery destinations (29.3\%); market demand in neighboring countries is strong or expected in the future (27.8\%); high-quality and cheap labor force can be secured in host countries (17.4\%). ${ }^{1}$ (METI 2015) Therefore, Asian countries become emerging markets for Japanese MNCs in recent years, especially China. However, with the acceleration of Japan's outward FDI, a fear peaked among researchers that such vertical FDI will cause the closure of domestic plants and decrease in export and domestic productivity of Japan. As a consequence, it will result in unemployment problem in Japan, which is the so-called Hollowing-Out effect, especially in the manufacturing industry.

This paper uses input-output analysis to investigate the impact of outward FDI on domestic production and employment in Japan's manufacturing industries through firmlevel data. The impact is calculated from three effects: export promotion effect, export substitution effect and import inverse effect. Then, compare the results with 20 years ago in preceding researches to verify the "Hollowing-Out Effect" in Japan caused by the transfer of manufacturing industry.

\section{Literature review}

This section will introduce some literature about the relationship of outward FDI and employment in the home country. The term "Hollowing-Out Effect" was firstly put forward in 1980s in USA. ${ }^{2}$ The USA incurred inflation at that time so that the Reagan administration adopted a tight monetary policy. Therefore, the US manufacturing industry began to transfer production plants overseas because of the high interest rate and dollar rate in USA. Lipsey (1995) initially revealed that overseas production of US affiliates in developing countries reduced the employment of home country. He stated that US manufacturing multinationals allocated their labor-intensive business activities to developing countries which would reduce the labor intensity in US domestic production. Blomström et al. (1997) investigated the relationship between outward FDI and employment of the USA. He found that the US companies allocated their labor-intensive productions in low-wage developing countries which reduced the employment of the home land. Lipsey (2000) found that the US companies appeared to reduce the employment at home land with the increase in production of overseas affiliates, which is contrast with Japan.

In 1990s, "Hollowing-Out Effect" also became one of the primary economic problems in Japan. Many Japanese political and economic experts started to make research on the relationship of outward FDI and employment at the home country. The Ministry of Labor's of Japan published "White Paper on Labor" (1994) which analyzed the influence of FDI on Japan's domestic employment from 1986 to 1991. The result showed that the total effect of Japan's outward FDI had negative influence on domestic employment in 1986 and 1991 and positive influence in 1987-1990. Also, the influence of Japan's outward FDI was marginal around 1990. The Ministry of International Trade and Industry (MITI) of Japan presented an estimation in "The Overseas Business Activities of

\footnotetext{
${ }^{1}$ Basic Survey on Overseas Business Activity (BSOBA) conducted by Japan Ministry of Economy, Trade and Industry (METI).

2 Business Week (1986). The Hollow Corporation. Business Week, March 3, pp. 52-75.
} 
Japanese Companies" (1997) for the period from 1991 to 1995. The results showed that the effect of Japan's outward FDI was positive in 1991 and 1992 and negative from 1993. It revealed that outward FDI reduced Japan's employment with the acceleration of itself. The Ministry of Health, Labor and Welfare's (MHLW) of Japan presented the similar results in "White Paper on Labor Economy" (2003). It showed that almost $4 \%$ of the employees in Japan's manufacturing industry lost their job because of the negative effect of outward FDI. Moreover, it stated that Japan's outward FDI to Asian countries is the primary reason for the job losses. Fukao and Yuan (2001) suggested that Japanese FDI in East Asia caused around 600,000 workers losing their job in Japan. However, market-oriented FDI of Japanese MNCs in East Asia increased the employment of Japan. Fujikawa and Watanabe (2004) indicated that Japanese outward FDI caused unemployment and had negative effect on domestic production. Simeon (2011) used time series regression to examine the "Hollowing-Out" effect in Japan's manufacturing sector. He showed that outward FDI and other domestic factors would cause unemployment and recession in the home country.

The literature mentioned above insisted that overseas production of labor-intensive industries tended to reduce the employment at the home country. However, many researchers put forward that outward FDI creates more job opportunities in parent countries. Hanson et al. (2003) indicated that the increase in sales of US foreign affiliates raises the labor demand of home country. Desai et al. (2005) found evidence that the expansion of foreign production has stimulated the scale expansion of US home corporations. Hijzen et al. (2007) found that Japan's outward FDI enhances domestic output and employment of parent companies. Yamashita and Fukao (2008) suggested that Japan's overseas business activities have helped to alleviate the pressure of home unemployment in Japan's manufacturing industries to a certain extent.

Different types of outward FDI can also complicate the different effect of foreign economic activities (Caves 1996). It is hard to use one simplistic theory to explain the effects of overseas investment on the home country. The complicated impact of increased outward FDI on domestic economic activity of home country can be either positive or negative, depending on the scale of foreign operations and the substitution effects (Hanson et al. 2003). Harrison and Mcmillan (2006) found significant evidence that the employment of US overseas companies in developing countries substituted for the employment of parent corporations in manufacturing industries. On the contrary, the employment of US overseas branches in developed countries is complementary with parent firms. Some studies also analyze the impact on the home country according to different types of FDI. Hayakawa et al. (2013) considered that horizontal FDI increases demand for non-production workers and vertical FDI increases demand for skilled production workers in the home country. Lee et al. (2015) argued that labor-seeking outward FDI of Japan's MNEs reduced home employment and market-seeking outward FDI of Japan's MNEs increased home employment. Hijzen et al. (2011) found that horizontal FDI has a significant positive effect on domestic productivity of home country, but not vertical FDI. Debaere et al. (2010) stated that neither of types of FDI have positive impact on home countries' employment.

The literature above investigated the impact of outward FDI on home counties' employment, either positive or negative. However, they all covered a short time period. 
This paper is based on Fujikawa and Watanabe (2004), using input-output empirical analysis to examine the impact of Japanese foreign production activities on domestic output and employment and then compared two calculation results to see the change of "Hollowing-Out" effect in Japan's manufacturing industry in a long time period. It is helpful to observe the impact of outward FDI on employment of the home country in different stages of investment.

\section{Methods}

\subsection{Leontief import endogenous open model}

In a general way, there are four stages of outward FDI and the impacts to the domestic economy are different. In the first stage, the home country exports the capital for the construction of production plants to the host country, which will increase the export of the home country. In the second stage, the home country exports intermediate goods to the host country for production. The capital output in these two preliminary stages leads to the export promotion effect to the home country. In the third stage, affiliates in the host country have enough productivity to satisfy the demand of local market and start to export to other countries instead of the home country; hence, outward FDI has substitution effect on export of the home country. In the last stage, the home country imports from the host country, which is called boomerang effect. This paper analyzes the impact of outward FDI on Japan's domestic economy through these three different effects.

The overseas investment activities of Japanese multinational corporations cause the change of domestic production in Japan via the demand of Japan's capital. The change of the domestic production can be calculated by Leontief import endogenous open model. According to the model, we have supply-demand equivalent equation as follows:

$$
(\mathbf{I}-\hat{\mathbf{M}}) \mathbf{A} \mathbf{x}+(\mathbf{I}-\hat{\mathbf{M}}) \mathbf{f}+\mathbf{e}=\mathbf{x}
$$

Therefore, we can achieve equilibrium production model to calculate the domestic production change of Japan as follows:

$$
\mathbf{x}=[\mathbf{I}-(\mathbf{I}-\hat{\mathbf{M}}) \mathbf{A}]^{-1}[(\mathbf{I}-\hat{\mathbf{M}}) \mathbf{f}+\mathbf{e}]
$$

where $\mathbf{x}, \mathbf{f}$ and $\mathbf{e}$, respectively, represent the domestic production, the domestic final demand and the export; $\mathbf{I}$ is the identity matrix; and $\mathbf{A}$ is the direct input coefficient matrix. $\hat{\mathbf{M}}$ is the diagonal matrix of import ratio, and the definition of diagonal elements $m_{i}$ is as follows:

$$
m_{i}=M_{i} /\left(\sum_{j} a_{i j} X_{j}+f_{i}\right)
$$

where $M_{i}$ represents the import amount of industry $i$ and the denominator is the total output of industry $i$ except export, that is to say, the sum of intermediate demand $\sum_{j} a_{i j} X_{j}$ and domestic final demand $f_{i}$ of industry $i$.

In order to investigate the impact of OFDI on employment, here multiply Eq. (2) by labor coefficient as follows:

$$
\mathbf{n}=\hat{\mathbf{N}} \mathbf{x}
$$


where $\mathbf{n}$ represents the quantity of employment influenced by OFDI; $\hat{\mathbf{N}}$ is the diagonal matrix of labor coefficient (the necessary number of employees every unit of production need); and $\mathbf{x}$ represents the domestic production of Japan in Eq. (2).

\subsection{Data source}

The input-output tables of Japan from 2000 to 2014 are calculated by the Ministry of Economy, Trade and Industry of Japan (METI). The employment table of 2000-2014 is from World Input-Output Database (WIOD). The detailed data of Japan's overseas corporations are collected from the Survey on Overseas Business Activities (SOBA) carried out by METI.

\subsubsection{Export promotion effect}

As mentioned before, outward FDI promotes the export of host country in the early stage. To estimate this effect, we take the amount of intermediate goods that Japan's overseas companies import from Japan in SOBA as the increment of export e in Eq. (2). As thus, we can achieve the export promotion effect.

However, the data of SOBA cannot identify which industry these intermediate goods imported from. For example, when overseas companies produce a car, they need to import not only automobile parts but also plastic products for decoration. Therefore, this paper analyzed two situations when calculated export promotion effect. In the first case, we supposed that overseas corporations import intermediate products only from the same industries. In the other case, we supposed that these intermediate products are imported from different industries and have the same input coefficient as production industries in Japan.

\subsubsection{Export substitution effect}

Overseas affiliates substitute for Japan's export by sales in the host country and export to a third country. However, it is hard to measure the substitution effect of the latter. Actually, the export to a third country may take the place of Japan's export. It may also replace the local products of the host country or the import from other countries. Therefore, this paper only investigated the export substitution effect of local sales. We take the local sales amount of Japan's overseas corporations as the decrease in export $\mathbf{e}$ in Eq. (2). These data also come from SOBA.

\subsubsection{Import inverse effect}

With the increase in competitiveness, overseas affiliates start to export to the home country-Japan. As a result, the final demand of Japan will decrease because of this inverse input from the host country. This paper takes the export from Japan's overseas affiliates to Japan as the decrease in final demand $\mathbf{f}$ in Eq. (2). The data of sales to Japan are also collected by SOBA.

\section{Results}

This paper calculated the impact of Japanese outward FDI on domestic production and employment from 2000 to 2014, using the input-output model above. This part will only show the result table of 2014. The results of 2000-2014 will be shown by graph to observe the trend of impact. 


\subsection{The impact of Japanese outward FDI on domestic production of manufacturing industry}

Table 1 shows the impact of outward FDI on domestic production of Japan's manufacturing industry in 2014. The impact has been divided into three parts-export promotion effect, export substitution effect and inverse import effect. Export promotion effect $\mathrm{A}$ is the case when Japanese overseas corporations import intermediate products only from the same industries of parent country. Export promotion effect $B$ is the case when intermediate products are imported from different industries and have the same input coefficient as production industries in Japan.

From Table 1, we can observe that export promotion effect is positive, and export substitution effect and inverse import effect are negative, so the total effect of Japan's outward FDI is negative. In export promotion effect A, transportation equipment industry has the most positive impact on domestic production. In export promotion effect $B$, iron and steel industry has the most positive impact and transportation equipment industry ranked second. In export substitution effect, transportation equipment industry has the most negative effect. In inverse import effect, information and communication electronics equipment industry and transportation equipment industry have very huge impact. In both total effect case $\mathrm{A}$ and case $\mathrm{B}$, transportation equipment industry has the most impact and it is negative, which is the main reason that caused total effect of Japan's outward FDI to be negative. Also, among three effects, export substitution effect is even greater other twos which determined total effect.

The trend of the impact from 2000 to 2014 can be observed from Fig. 3. The export promotion effect showed in the graph is case A. This effect has been always positive in these years and reached the peak in 2007. In 2014, the impact of export promotion effect on Japan's domestic production reached 40,729 billion yen, increased two times by 2000 . It is obvious that export substitution effect is more significant than other two effects. It increased rapidly from 2000 to 2007, then decreased because of the financial crisis and recovered from 2010. In 2014, the impact of export substitution effect on domestic production has reached 136,094 billion yen, almost two times of 2000. The inverse import effect has small impact compared with two others. As a consequence, the total effect of Japan's outward FDI on domestic production has increased from 58,329 to 104,456 billion yen, almost two times.

\subsection{The impact of Japanese outward FDI on employment of manufacturing industry}

The calculation result of the impact on employment is shown in Table 2. Both the total effect case A and case B are negative, which means that Japanese outward FDI actually caused unemployment in Japan. Overseas production of Japanese affiliates resulted in 3.23 million people losing their job in Japan in 2014, which is almost one third of employees of Japan's manufacturing industry in that year. Export promotion effect is positive, so it can stimulate the employment. Export substitution effect and inverse import effect are both negative, which cause unemployment. In case A, the information and communication electronics equipment industry has the most significant impact. In case $\mathrm{B}$, the metal products industry has the greatest impact on employment. In export substitution effect, the transportation equipment industry 
Table 1 Impact on the domestic production of Japan's manufacturing industry in 2014

\begin{tabular}{|c|c|c|c|c|c|c|c|}
\hline $\begin{array}{l}\text { (Billion } \\
\text { Yen) }\end{array}$ & $\begin{array}{l}\text { Domestic } \\
\text { production }\end{array}$ & $\begin{array}{l}\text { Export } \\
\text { promotion } \\
\text { effect A }\end{array}$ & $\begin{array}{l}\text { Export } \\
\text { promotion } \\
\text { effect B }\end{array}$ & $\begin{array}{l}\text { Export } \\
\text { substitution } \\
\text { effect }\end{array}$ & $\begin{array}{l}\text { Inverse } \\
\text { import } \\
\text { effect }\end{array}$ & $\begin{array}{l}\text { Total effect } \\
\text { A }\end{array}$ & $\begin{array}{l}\text { Total effect } \\
\text { B }\end{array}$ \\
\hline Food & 36,853 & 488 & 4258 & -6736 & -269 & -6517 & -2747 \\
\hline Textiles & 3323 & 222 & 380 & -991 & -107 & -876 & -718 \\
\hline $\begin{array}{l}\text { Lumber, } \\
\text { wood, } \\
\text { paper and } \\
\text { pulp }\end{array}$ & 11,515 & 882 & 2373 & -3123 & -164 & -2406 & -914 \\
\hline Chemicals & 28,250 & 3589 & 5563 & $-14,847$ & -592 & $-11,849$ & -9875 \\
\hline $\begin{array}{l}\text { Petroleum } \\
\text { and coal }\end{array}$ & 22,361 & 2798 & 4964 & -4161 & -174 & -1536 & 629 \\
\hline $\begin{array}{l}\text { Ceramic, } \\
\text { stone } \\
\text { and clay } \\
\text { products }\end{array}$ & 6427 & 716 & 1047 & -2106 & -90 & -1480 & -1149 \\
\hline $\begin{array}{l}\text { Iron and } \\
\text { steel }\end{array}$ & 30,158 & 3871 & 9152 & $-14,792$ & -35 & $-10,956$ & -5675 \\
\hline $\begin{array}{l}\text { Nonferrous } \\
\text { metals }\end{array}$ & 9154 & 1386 & 1953 & -4847 & -340 & -3800 & -3234 \\
\hline $\begin{array}{l}\text { Metal prod- } \\
\text { ucts }\end{array}$ & 11,320 & 943 & 1855 & -2993 & -254 & -2304 & -1392 \\
\hline $\begin{array}{l}\text { General- } \\
\text { purpose } \\
\text { machin- } \\
\text { ery }\end{array}$ & 9853 & 697 & 1097 & -2737 & -292 & -2332 & -1932 \\
\hline $\begin{array}{l}\text { Production } \\
\text { machin- } \\
\text { ery }\end{array}$ & 15,403 & 918 & 1390 & -3109 & -314 & -2505 & -2032 \\
\hline $\begin{array}{l}\text { Business- } \\
\text { oriented } \\
\text { machin- } \\
\text { ery }\end{array}$ & 6307 & 378 & 669 & -1579 & -885 & -2086 & -1795 \\
\hline $\begin{array}{l}\text { Electrical } \\
\text { machin- } \\
\text { ery }\end{array}$ & 15,601 & 1704 & 1849 & -5417 & -700 & -4414 & -4268 \\
\hline $\begin{array}{l}\text { Informa- } \\
\text { tion and } \\
\text { commu- } \\
\text { nication } \\
\text { electron- } \\
\text { ics equip- } \\
\text { ment }\end{array}$ & 17,979 & 5317 & 2242 & -9920 & -2081 & -6684 & -9759 \\
\hline $\begin{array}{l}\text { Transpor- } \\
\text { tation } \\
\text { equip- } \\
\text { ment }\end{array}$ & 52,910 & 14,362 & 8608 & $-49,274$ & -2005 & $-36,917$ & $-42,672$ \\
\hline $\begin{array}{l}\text { Other } \\
\text { manu- } \\
\text { facturing } \\
\text { industries }\end{array}$ & 23,312 & 2458 & 3882 & -9465 & -788 & -7795 & -6371 \\
\hline Total & 300,726 & 40,729 & 51,282 & $-136,094$ & -9091 & $-104,456$ & $-93,903$ \\
\hline
\end{tabular}

Source: calculated by author

has the greatest impact. In inverse import effect, the information and communication electronics equipment industry has the greatest impact. As a result, both total effect $A$ and effect $B$ are negative and the transportation equipment industry has the greatest impact on Japan's employment. Among three effects, export substitution effect is 


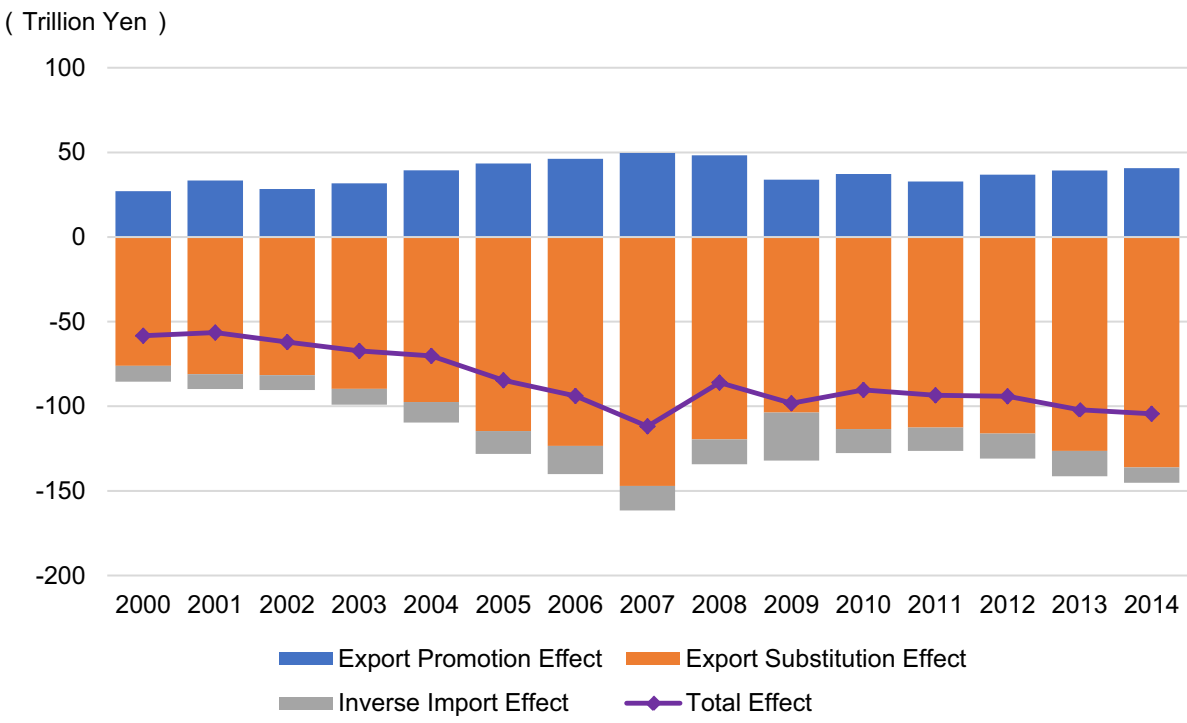

Fig. 3 Impact on the domestic production of Japan (2000-2014). Remark: export promotion effect is case A. Source: calculated by author

also larger than export promotion effect and inverse import effect, which is the primary reason for unemployment.

According to the total effect from 2000 to 2014 shown in Fig. 4, we can investigate the trend of impact of outward FDI on the employment of Japan. The total effect is always negative and increased from 1.91 million in 2000 to 3.23 million in 2014. Export substitution effect is undoubtedly the most among three effects. It slumped in 2008 because of the global depression after financial crisis which caused total effect also slumped. The export of Japanese overseas affiliates to other countries decreased a lot in 2008. With the recover of Japan's economy, the total effect rose rapidly in 2009, especially inverse import effect. Although decreased a little in 2010, it expanded continuously from 2011.

\subsection{Comparison of 1990-1999 and 2000-2014}

Fujikawa and Watanabe (2004) investigated the impact of outward FDI on the employment of Japan from 1990 to 1999, and the result is shown in Fig. 5. This period is an early stage of Japan's foreign expansion, so the amount of unemployment had increased continuously with the rapid growth of Japan's outward FDI. However, compared with the period of 2000-2014, the unemployment problem has not been so serious. The total effect on unemployment of 2014 is about 3 million bigger than 1999. Export promotion effect increased rapidly in the period 2000-2014, which makes the gap between positive and negative effects greater. It is obvious that the negative impact of outward FDI on Japan's domestic employment has become much serious with the continuously expansion of Japanese foreign investment in the period of 2000-2014 compared with 1990-1999. The "Hollowing-Out Effect" in Japan's manufacturing industry is gradually serious with the development of overseas expansion. 
Table 2 Impact on the employment of Japan's manufacturing industry in 2014

\begin{tabular}{|c|c|c|c|c|c|c|c|}
\hline (Million) & $\begin{array}{l}\text { Total } \\
\text { employees }\end{array}$ & $\begin{array}{l}\text { Export } \\
\text { promotion } \\
\text { effect A }\end{array}$ & $\begin{array}{l}\text { Export } \\
\text { promotion } \\
\text { effect B }\end{array}$ & $\begin{array}{l}\text { Export } \\
\text { substitution } \\
\text { effect }\end{array}$ & $\begin{array}{l}\text { Inverse } \\
\text { import } \\
\text { effect }\end{array}$ & $\begin{array}{l}\text { Total effect } \\
\text { A }\end{array}$ & $\begin{array}{l}\text { Total effect } \\
\text { B }\end{array}$ \\
\hline Food & 1.280 & 0.017 & 0.148 & -0.234 & -0.018 & -0.235 & -0.104 \\
\hline Textiles & 0.400 & 0.027 & 0.046 & -0.119 & -0.019 & -0.112 & -0.092 \\
\hline $\begin{array}{l}\text { Lumber, } \\
\text { wood, } \\
\text { paper and } \\
\text { pulp }\end{array}$ & 0.752 & 0.058 & 0.155 & -0.204 & -0.037 & -0.183 & -0.086 \\
\hline $\begin{array}{l}\text { Petroleum } \\
\text { and coal }\end{array}$ & 0.024 & 0.003 & 0.005 & -0.005 & -0.001 & -0.002 & 0.000 \\
\hline Chemicals & 0.420 & 0.053 & 0.083 & -0.221 & -0.021 & -0.189 & -0.160 \\
\hline $\begin{array}{l}\text { Ceramic, } \\
\text { stone } \\
\text { and clay } \\
\text { products }\end{array}$ & 0.310 & 0.035 & 0.050 & -0.102 & -0.014 & -0.081 & -0.065 \\
\hline $\begin{array}{l}\text { Metal prod- } \\
\text { ucts }\end{array}$ & 1.385 & 0.170 & 0.355 & -0.619 & -0.070 & -0.519 & -0.334 \\
\hline $\begin{array}{l}\text { Informa- } \\
\text { tion and } \\
\text { commu- } \\
\text { nication } \\
\text { electron- } \\
\text { ics equip- } \\
\text { ment }\end{array}$ & 1.164 & 0.344 & 0.145 & -0.642 & -0.170 & -0.468 & -0.667 \\
\hline $\begin{array}{l}\text { Electrical } \\
\text { machin- } \\
\text { ery }\end{array}$ & 0.483 & 0.053 & 0.057 & -0.168 & -0.029 & -0.144 & -0.139 \\
\hline $\begin{array}{l}\text { Machinery } \\
\text { and } \\
\text { equip- } \\
\text { ment }\end{array}$ & 0.845 & 0.053 & 0.085 & -0.199 & -0.048 & -0.194 & -0.162 \\
\hline $\begin{array}{l}\text { Transpor- } \\
\text { tation } \\
\text { equip- } \\
\text { ment }\end{array}$ & 1.097 & 0.298 & 0.179 & -1.022 & -0.070 & -0.794 & -0.914 \\
\hline $\begin{array}{l}\text { Other } \\
\text { manu- } \\
\text { facturing } \\
\text { industries }\end{array}$ & 0.832 & 0.088 & 0.139 & -0.338 & -0.057 & -0.307 & -0.256 \\
\hline Total & 8.993 & 1.198 & 1.446 & -3.872 & -0.553 & -3.227 & -2.979 \\
\hline
\end{tabular}

Source: calculated by author

\section{Summary and policy recommendations}

This paper investigated the impact of outward FDI on domestic production and employment in Japan's manufacturing industry by input-output analysis. Three effects are analyzed separately: export promotion effect, export substitution effect and import inverse effect. As a result, export promotion effect is positive, and export substitution effect and import inverse effect are negative. Export substitution effect has the most negative impact than the other two so that the total effect of Japan's outward FDI has negative impact on domestic production and employment, which means that outward FDI caused the decrease in domestic production and employment in Japan's manufacturing industry. Among these manufacturing industries, the transportation equipment industry has the greatest negative impact. The unemployment 


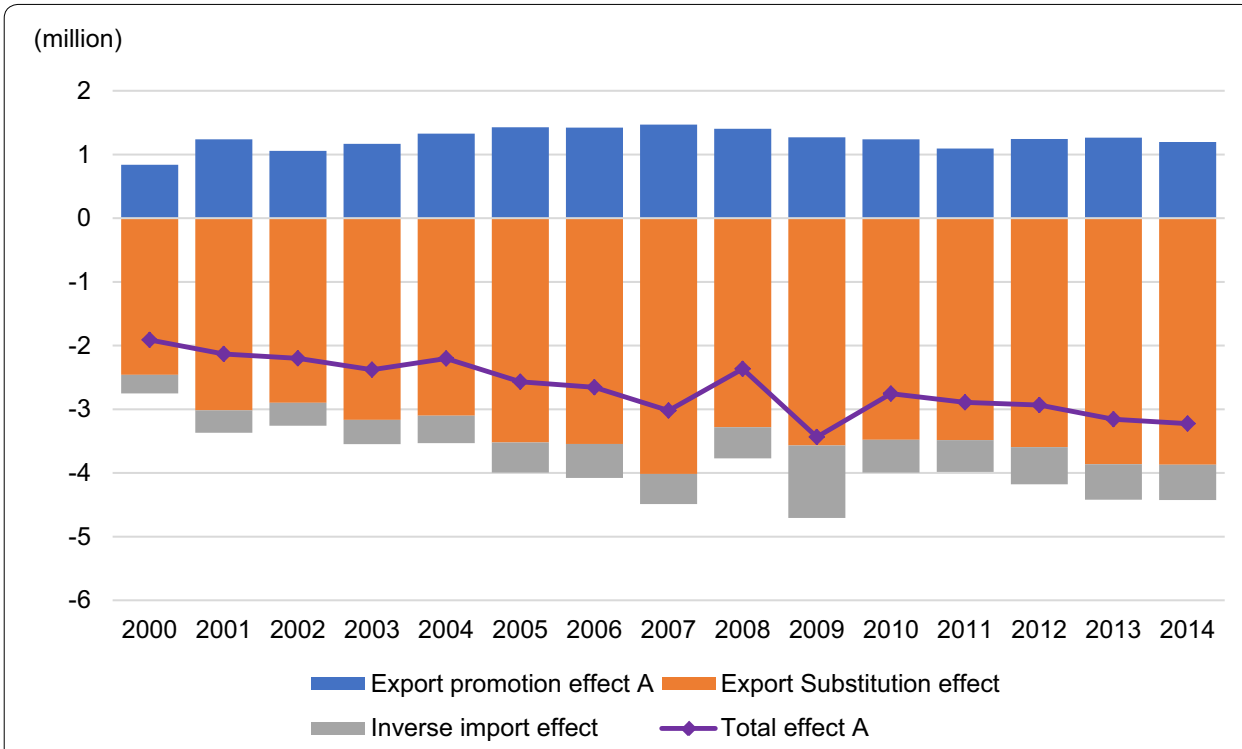

Fig. 4 Impact on the employment of Japan (2000-2014). Remark: export promotion effect is case A. Source: calculated by author

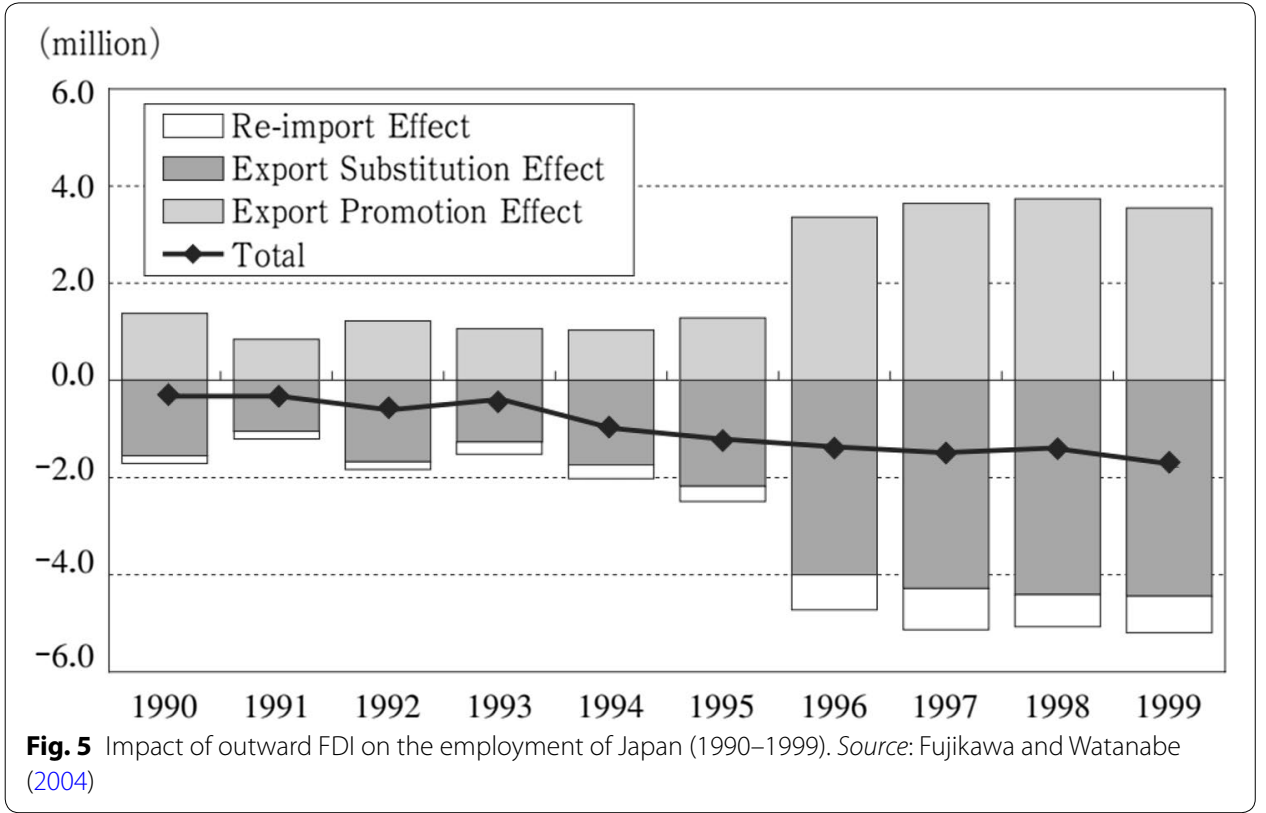

in this industry is more than other industries because production plants transferred to foreign countries. From the trend of the result, we can know that the unemployment caused by foreign investment became serious from 2000, although it decreased in 2008 because of depression.

Also, after the comparison of 1990-1999 and 2000-2014, we can observe that the "Hollowing-Out" effect in Japan's manufacturing industries has actually become serious in recent decades with the development of Japan's overseas expansion. The unemployment problem cannot be neglected in the later stages of outward FDI. It is necessary 
for Japanese government to find other industries to absorb these unemployment workers caused by foreign investment, such as service industries. It is an important issue for Japan how to change the structure of economy to solve the "Hollowing-Out" problem, considering its outward FDI is increasing continually.

From the experience of the USA, Japanese government has made efforts to alleviate the influence of the overseas shift of industrial industry. Still, the government can consider the following policies to improve.

1. Develop the service industry more. Compared with the USA, the development of new service industry in Japan is still not enough. The service industry is the most value-added industry to absorb the labor force, such as education, health and consultation.

2. Encourage the innovation and technology. The government should invest more in development and research to maintain the advantage of Japan, especially in ITrelated industry.

3. Attract more inward FDI. Inward FDI can bring capital and create new employment position. Also, an open market is very important for trade and technology innovation.

In a word, it is important to enlarge the openness and development new technology. Japan should continue to improve the industrial structure to alleviate the negative impact of outward FDI.

Authors' contributions

GH carried out the input-output analysis and drafted the manuscript. The author read and approved the final manuscript.

\section{Acknowledgements}

The author would like to express sincere gratitude to the China Scholarship Council (CSC) for financial support for seeking the doctor degree, as well as the helpful comments from reviewers.

\section{Competing interests}

The authors declare that they have no competing interests.

\section{Availability of data and materials}

World Input-Output Database: http://www.wiod.org/home. Japan Ministry of Economy, Trade and Industry: http://www. meti.go.jp/statistics/tyo/kaigaizi/result/h27data.html.

\section{Funding}

Not applicable.

\section{Publisher's Note}

Springer Nature remains neutral with regard to jurisdictional claims in published maps and institutional affiliations.

Received: 25 May 2018 Accepted: 8 October 2018

Published online: 16 October 2018

\section{References}

Blomström M, Fors G, Lipsey RE (1997) Foreign direct investment and employment: home country experience in the United States and Sweden. Econ J 107(445):1787-1797

Business Week (1986). The Hollow Corporation. Business Week, March 3, pp 52-75

Caves RE (1996) Multinational enterprises and economic analysis, 2nd edn. Cambridge University Press, Cambridge

Debaere P, Lee H, Lee J (2010) It matters where you go: outward foreign direct investment and multinational employment growth at home. J Dev Econ 91(2):301-309

Desai M, Foley F, Hines J (2005) Foreign direct investment and domestic economic activity. NBER Working Paper Series No. 11717

Fujikawa K, Watanabe T (2004) Foreign direct investment and employment. Bus J PAPPIOS 12(2):3-16 
Fukao K, Yuan T (2001) Japanese outward FDI and hollowing out. RIETI Discussion Paper Series No. 003 Hanson GH, Mataloni RJ, Slaughter MJ (2003) Expansion abroad and the domestic operations of US multinational firms. http://mba.tuck.dartmouth.edu/pages/faculty/matthew.slaughter/. Accessed 1 Mar 2018

Harrison AE, McMillan MS (2006) Outsouring jobs? Multinationals and US employment. NBER Working Paper Series No. 12372

Hayakawa K, Matsuura T, Motohashi K, Obashi A (2013) Two-dimensional analysis of the impact of outward FDI on performance at home: evidence from Japanese manufacturing firms. Jpn World Econ 27(4):25-33

Hijzen A, Inui T, Todo Y (2007) The effects of multinational production on domestic performance: evidence from Japanese firms. RIETI Discussion Paper Series, 07-E-006

Hijzen A, Jean S, Mayer T (2011) The effects at home of initiating production abroad: evidence from matched French firms. Rev World Econ 147(3):457-483

Lee IH, Makino S, Hong E (2015) Outward FDI does not necessarily cost domestic employment of MNEs at home: evidence from Japanese MNEs. IEEE Int Conf IC Des Technol 2015:194-197

Lipsey RE (1995) Outward direct investment and the US economy. The effects of taxation on multinational corporations. University of Chicago Press, Chicago, pp 7-33

Lipsey RE, Ramstetter ED, Blomstrom M (2000) Outward FDI and parent exports and employment: Japan, the United States, and Sweden. Global Econ J 1:285-302

Ministry of Labor (Ministry of Health, Labor and Welfare at present) (1994) White paper on labor. Japan Institute of Labor. https://www.mhlw.go.jp/index.html. Accessed 13 Feb 2018

Simeon R (2011) The hollowing out phenomenon in Japan. J Bus Econ Res 1(6):1-12

Yamashita N, Fukao K (2008) The effects of overseas operations on home employment of Japanese multinational enterprises. Hi-Stat Discuss Pap Ser 2008(4):561-562

\section{Submit your manuscript to a SpringerOpen ${ }^{\circ}$ journal and benefit from:}

- Convenient online submission

Rigorous peer review

- Open access: articles freely available online

- High visibility within the field

Retaining the copyright to your article

Submit your next manuscript at $\mathbf{s p r i n g e r o p e n . c o m ~}$ 